\title{
CORPORATE GOVERNANCE: WILL MODERATE THE EFFECT ACCOUNTING CONSEVATISM TOWARD EQUITY VALUATION
}

\author{
Ratna Wijayanti Daniar Paramita, Noviansyah Rizal \\ STIE Widya Gama Lumajang \\ pradnyataj@gmail.com \\ noviansyah.rizal@gmail.com
}

\begin{abstract}
This study aimed to examine the effect of conservatism on equity valuation with corporate governance variable as moderating variable.The study was conducted on 365 manufacturing companies that meet the criteria of observations in 2011 to 2015 . The variables used in this research is accounting consevatism as independent variables, corporate governance as moderating variable and equity valuation as dependen variable. The board of directors and manajerial ownership in this article as a proxy of corporate governance. Studies show conservatism affect the equity valuation. The higher the level of conservatism that increasingly reflects the reality of the financial statements and this would be a good response from investors. Board of commisioners and managerial ownership does not strengthen the influence of conservatism on equity valuation. Manejerial ownership in manufacturing companies does not affect the management to apply accounting conservatism.
\end{abstract}

Keywords: equity valuation, accounting conservatism, corporate governance

\section{INTRODUCTION}

The company's goal is to optimize the long-term value of the company. When the company suffered a loss or experiencing financial difficulties then change the value relevance of the data of the financial information. The results showed the influence of certain conditions on the strength of the relationship between stock prices and earnings as well as the relevance of the accounting value of other variables such as the book value of equity, operating cash flow [1]

The concept of unity of business to separate the interests of management and owners, information on shareholder equity is very important because it shows the relationship between the company and shareholders. Information reporting purposes shareholder equity is to provide information to interested parties about the efficiency and the stewardship of management [2]

Investors need to assess the equity they own in the company through the company's financial statements submitted. Equity valuation analysis emphasizes profit and other accounting measurements to calculate the value of the company. Proxy Assessment can use the equity market to book ratio because it is influenced by the accounting method used by the company. [3] use the market to book ratio that reflects the market value relative to the value of the company.

Financial statements that describe the company's performance in managing resources management. The financial statements must meet the objectives, rules and principles of accounting in accordance with generally accepted standards in order to produce financial statements that can be justified and useful for every user. In an effort to enhance financial reporting and to be accounted for by the management was born the concept of conservatism. Defines conservatism as a pessimistic outlook in accounting [2].

Until now, the principle of conservatism is still considered a controversial principle. There are many criticisms that emerged, but there also support the implementation of the principle of conservatism. Critics like Monahan stated that the more conservative accounting, the book value of equity is reported to be increasingly biased. But the part that supports such research by proved that profits and assets are calculated with conservative accounting can improve the quality of earnings that can be used to assess the company [4].

Accounting conservatism in this study was measured using the accrua of operating which is the difference between net income and cash flow [5] Operating accrual is the amount of accrued operational activities of the company, while the cash flow is cash flow used operasinal. Operating major accrual includes accounts receivable and inventory and liabilities. This account is a classic account that is used to manipulate earnings to achieve the purpose of reporting.

Research support and reject the application of accounting conservatism on the influence of the equity valuation of the company, the researchers incorporate Corporate Governance as a moderating variable is the variable that strengthen or weaken the relationship between conservatism against the equity valuation of the company. Corporate Governance in Indonesia is absolutely necessary, given the good corporate governance requires a good management in an organization. The application of conservative accounting in the financial statements is influenced by corporate governance mechanisms. According to the corporate governance mechanism can be classified in two groups. The first is the company's internal mechanism consisting of the structure of ownership and management structure. The second is external mechanism consisting of the rule of law and corporate control market.

This study measured the company's internal mechanism as the moderating variable, the ownership structure will be used variable managerial ownership. Bell states that the selection of an accounting method related to the principle konservatime also influenced by the ownership structure as a corporate governance mechanism. management structure using a variable number of commissioners. Among the various factors that can encourage the creation of effective corporate management, board of directors is the main factor affecting the behavior of managers in the management of companies included in the application of accounting conservatism policy.

The purpose of this study to analyze and determine the effect of accounting conservatism to the equity valuation of the company, the influence of the effect of managerial ownership on accounting conservatism relationship with the equity valuation of companies and influence the effect of the number of commissioners to the relationship between accounting conservatism with equity valuation company.

\section{THEORY DAN HIPOTESIS}

This section will describe the theory underlying accounting information asymmetry, conservatism and Corporate governance.

\section{A. Information Asymmetry}

Agency theory implies owned Information asymmetry between principal and agent. Information asymmetry is a condition when the agent has more information about the company's prospects are not owned by the principal. Agency theory is a theory used to explain the conflict between agent and principal. The existence of a conflict between the two parties to explain their economic consequences on the contracting process. The underlying assumption of agency theory is the existence of uncertainty and information asymmetry. The parties involved in contracting are assumed to act rationally, in the sense of seeking to maximize his expected utility [6]

Principal and agent are those who continue to strive to maximize utility, [6] Jensen and Meckling assess any strong reason to believe that the agent will not always act in the best interests of the principal. In this case the principal can limit this situation by establishing an appropriate incentive for the agent. Other things can also be done to limit the principal agent deviant actions, that is by designing a supervisory or monitoring was accurately. However, information asymmetry can not be eliminated, it can only be "full disclosure" [7]

Definition of information asymmetry given Pyndick is "one side of the negotiation process has better information than the other" from that definition in mind that information asymmetry will occur when there are two sides that have different information or more than others when it will 
make the contracting process. [8] The information asymmetry as the situation formed by the principal (shareholders) do not have enough information regarding the performance of the agent (manager) so that the principal can never determine the contribution of efforts agent on the results of companies that actually. Information asymmetry can be addressed by requiring full disclosure of management conduct (full disclosure) on the condition of the company in the financial statements. In addition, it can also do surveillance (monitoring) the actions of the management through an independent auditor.

Given the presentation of financial information by the company will bring economic consequences for the company and its investors, the presentation of quality information is expected to be consequential on lowering the asymmetry of information between the company and its investors the consequences of the economic quality of financial reporting arising for investors' assessment that is information asymmetry [9].

\section{B. Conservatism}

Signal theory explains that the signaling is done by managers to reduce information asymmetry. Managers provide information through the financial statements that they apply the accounting policy conservatism thus generating profits more qualified for this principle prevents companies taking action to exaggerate profits and helps users of financial statements to present the earnings and assets not overstate [10].

The principle of conservatism has been the concept of accounting records which are widely applied in recent decades. The principle that has become the standard primary listing in the first three decades of the 20th century applied to offset optimism in management as well as their propensity mengoverstate financial statements. The concept of conservatism states that in uncertain circumstances state enterprise managers will determine treatment options or actions that are based on state accounting, expectations, events, or results that are considered less profitable.

Defines conservatism as the principle of prudence in financial reporting in which the company is not in a hurry in recognizing and measuring assets and income as well as quickly recognize losses and debts that are possibly going to happen [11]. The application of this principle resulted in selection of accounting methods directed at methods which reported earnings or assets lower and debt reporting higher losses. Thus, the lender will receive the protection of the downside risk of the balance sheet presents the understatement of net assets and the financial statements reported the bad news in a timely manner. [12] defines conservatism as the initial recognition of the cost and loss and delay the recognition of revenue and profit.

Watts stated that accounting conservatism emerged from incentives related to contract costs, litigation, tax and politically beneficial for companies to reduce agency costs and reducing excessive payments to parties such as managers, shareholders, courts and government. In addition, conservatism also led to understatement of earnings in the current period that could lead to the overstatement of earnings in the period - the next period, as a result understatement of the costs in the period. [5] suggest that conservative accounting as a tendency which is owned by an accountant who require higher levels of verification to recognize profit (good news in earnings) than recognize losses (bad news in earnings). So the bottom line accounting conservatism is delaying the recognition of unrealized profits, but admits the loss which has become the expectation.

Researchers typically use three forms of measurement to express conservatism, namely [13]: (1) Net asset measures One measure that can be used to determine the conservatism of financial statements such as those used by Beaver and Ryan (2000) is the value of assets understatement and liability overstatement. (2) Earning / accrual measure, this type of conservatism was measured using the accrual, which is the difference between the net income from operations to cash flow. Givoly accrual split into two, namely operating accrual accrual is the amount that appears in the financial statements as a result of the company's operations and nonoperating accrual is the amount of accruals arising out of operational results of the company. The smaller the size of the accrual of a company, shows that companies are increasingly applying conservative accounting principles. (3) Earning / stock market price Stock relation measure seeks to reflect changes in the value of the asset at the time of change of both the changes on income or profits in the value of asset-stock return still trying to report in accordance with time.

Equity is defined as a residual interest in the net assets to show that equity is not an obligation. This means that equity is not sacrifice future economic resources [14]. Because defined on the basis of assets and liabilities, the equity value also depends on how assets and liabilities are measured. Under conditions of uncertainty, the creditor has historically based its ruling on the conversion value of the lowest asset so that the presentation of assets in the balance sheet also follows this concept. Conservatism in the conservatism of the implementation of asset valuation has role in the determination of profit in the income statement. By lowering the value of assets (especially stocks of goods) at the end of the period due to falling prices, the net profit would be smaller. This will indirectly affect the value of equity investors.

\section{Corporate Governance}

Corporate governanceis a concept based on agency theory, is expected to serve as a tool to give confidence to investors that they would receive a return on funds they invest. Corporate Governance is concerned with how investors believe that managers will benefit investors. Research on corporate governance produce a variety of mechanisms that aim to ensure that management acts in harmony with the interests of shareholders (particularly minorityinterest). mechanisms Corporate governance are divided into two groups: (1) be internal mechanisms (internal mechanism) such as the composition of the board of directors / commissioners, managerial ownership and executive compensation. (2) external mechanisms such as control by the market and the level of debt financing.

The principles corporate governance applied of provides benefits such as: (1) minimizing agency costs by controlling conflicts of interest that may occur between the principal agent ; (2) minimize the cost of capital by creating a positive signal to the capital providers; (3) enhance the corporate image; (4) increasing the value of companies that can be seen from the cost of capital is low, and (5) improving financial performance andperceptions of stakeholder the company's future better.

Mechanism Corporate governance consists of a board of directors, audit committees and independent directors. Board of commissioners at a company with more emphasis on the monitoring of policy implementation functions of directors. The Board of Commissioners is expected to minimize the problems that arise between the agency's board of directors and shareholders. Board of commissioners is at the core of governance corporateshould be able to guarantee the quality of the information contained in the financial statements.

Corporate governance can be defined as an array of rules that define the relationship between shareholders, managers, creditors, government, employees, and internal and external stakeholders the other in accordance with their rights and responsibilities. In the mechanism of corporate governance, the board plays a very vital. In the financial reporting process, commissioners need accurate information in order to monitor the performance of managers effectively and efficiently. Accounting and financial reporting system is one of the reliable information in monitoring and evaluating managers and decision-making process and the determination of the strategy [15]. Conservatism is the one characteristic that is very important in the company's accounting system to assist the commissioners in reducing agency costs and improve the quality of financial reporting information that will ultimately increase the value of the company and its stock price

Stated that a strong board of directors will require a higher conservatism thus can help reduce agency costs arising from asymmetric information between managers and other parties. While [4] which states that conservatism will facilitate the implementation of corporate governance through its role as a monitoring function of the company's investment policy. By requiring faster recognition on expectations of losses, conservatism helps managers to identify projects that have a negative NPV or investments that have bad performance. Conservatism also will limit the losses that may arise from poorly performing investment decisions and thus will increase the value of the company [16].

Based of several articles can be concluded that the notion of good corporate governance is a set of systems that organize, manage and supervise the process of controlling business of a company to provide valueadded, as well as a form of concern to stakeholders, employees, creditors and the surrounding communities in order to create a pattern or working environment management clean, transparent, and professional. In Indonesia, the Code of Good Corporate Governance issued by the National Committee on Corporate Governance there are five principles that must be done by each company, namely: (1) Transparency (2) Accountability (3) Responsibility (4) independency (5) Fairness.

\section{1). Board of Commissioners}

Board of Commissioners is at the core of corporate governance that is assigned to guarantee the implementation of corporate strategy, overseeing management in managing the company, and require the implementation of accountability. In essence, the board is a mechanism to supervise and mechanism to provide guidance and direction to managers of the company. 
Given that management is responsible for increasing the efficiency and competitiveness of enterprises, while the board of directors is responsible for overseeing the management, the board of directors is the center of endurance and success of the company.

Board size is the exact number of commissioners in their duties. According to the general guidelines of Good Corporate Governance Indonesia, the number of commissioners should be tailored to the complexity of the company while maintaining effectiveness in decision making.

Characteristics of board of Commissioners in general and in particular the composition of the board can be a mechanism that determines earnings management action. The composition of the board of commissioners can make an effective contribution to the outcome of the process of preparing financial statements is qualified or avoid the possibility of fraudulent financial statements. Board of commissioners is at the core of corporate governance that is tasked to ensure the implementation of corporate strategy, overseeing management in managing the company, and require the implementation of accountability. The Board of Commissioners is a mechanism to oversee and provide guidance and direction to managers of the company.

Conservatism is one of the most important characteristics in the accounting system of a company that can help the board of directors in reducing agency costs and improve the quality of financial reporting information company that can ultimately increase the value of the company and its stock price. Board size is the exact number of commissioners in their duties. A large number of boards that can provide gains or losses in the company. the number of commissioners should be more or at least equal to the number of board members.

\section{2). Managerial ownership}

The owner (shareholder) aims to maximize wealth by looking at the present value of the cash flow generated by the investment company, while managers aimed at improving the growth and size of the company. Managerial ownership would help the union of interests between managers and shareholders. Managerial ownership will align the interests of management with shareholders, so that managers participate directly feel the benefits of the decisions taken and were also to bear the loss as a consequence of making the wrong decision.

Based on the classic agency theory, the greater ownership by inside directors (commissioners affiliated / commissioner outside independent directors) will lead to the suitability of interest between management and shareholders. According to [17], in the supervision of corporate governance mechanisms are divided into two groups: internal and external mechanisms.

Among the various factors that can encourage the creation of effective corporate management, board of directors is the main factor affecting the behavior of managers in the management of companies included in the application of accounting conservatism policy. Managerial ownership can be obtained from the number of shares held by directors and commissioners divided by number of shares outstanding. [18] states that the principle of conservatism is also influenced by the ownership structure as a corporate governance mechanism.

The research hypothesis:

$\mathrm{H}_{1}=$ Acoounting conservatism effect on equity valuation

$\mathrm{H}_{2}=$ Board of Commissioners strengthen the influence accounting conservatism on equity valuation

$\mathrm{H}_{3}=$ Managerial ownership strengthen the influence accounting conservatism on equity valuation

\section{RESEARCH METHOD}

\section{A. Desain Riset}

Design research in the form of equations that are hypothesized as follows:

$Y=\alpha+\beta_{1} X_{1}+\varepsilon$

$Y=\alpha+\beta_{1} X_{1}+\beta_{2} X_{2}+\beta_{3} X_{1} X_{2}+\varepsilon$

$Y=\alpha+\beta_{1} X_{1}+\beta_{4} X_{3}+\beta_{5} X_{1} X_{3}+\varepsilon$ where:

$\mathrm{y} \quad=$ equity valuation

$\mathrm{x}_{2} \quad=$ Accounting conservatism

$\mathrm{x}_{2} \quad=$ Board of Commissioners

$\mathrm{x}_{3} \quad=$ managerial ownership

$\alpha \quad=$ konstanta

$\varepsilon \quad=$ error

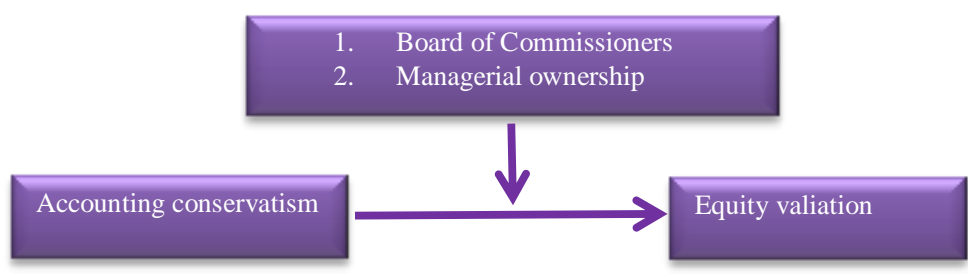

This study was designed to clarify influence of accounting conservatism to equity valuation with the corporate governance (board of comisioner and manager ownership) as variable moderating. The study population includes all manufacturing companies listed on the Indonesia Stock Exchange 2011-2015. Sampling using purposive sampling method. In this technique the samples taken are samples that have certain criteria in order to represent the population. Companies sampled must meet the following criteria:

a) companies whose shares remain active in operation from 2011 until December 2015, and to publish financial statements audited on a regular basis.

b) businesses have never experienced delisting from the Stock Exchange during the estimation period.

c) the company did not stop its activities in the stock market, did not stop its operation and does not enter into merger and does not change the status of the industrial sector.

d) the company did not experience a loss during the estimation period.

e) it has a complete data were used as variables in this study and is consistently reported at Bapepam.

Total sample used in this study is 73 companies.

\section{B. Definisi Operasional Variabel dan Skala Pengukuran}

Operasional variabel akan menguraikan variabel secara operasional mengacu pada definisi konseptual dan skala pengukuran. Dalam penelitian ini dapat dijelaskan definisi operasionalnya pada tabel 2 sebagai berikut:

TABEL 2

OPERASIONAL VARIABEL

\begin{tabular}{|c|c|c|}
\hline Variabel & Rumus & Skala \\
\hline $\begin{array}{l}\text { Equity } \\
\text { Valuation }\end{array}$ & market to book ratio $=\frac{\text { marker value per share }}{\text { book valeu per share }}$ & Ratio \\
\hline $\begin{array}{l}\text { Accounting } \\
\text { Conservatism }\end{array}$ & $\begin{array}{l}\text { Earning/accrual measure }= \\
\frac{\text { operating accrual }}{\text { cash flow operating }}\end{array}$ & Ratio \\
\hline $\begin{array}{l}\text { Board of } \\
\text { commisioner }\end{array}$ & $\begin{array}{l}\text { Ratio of board of commissioner internal and } \\
\text { ekternal }\end{array}$ & Ratio \\
\hline $\begin{array}{l}\text { Managerial } \\
\text { ownership }\end{array}$ & $\begin{array}{l}\text { manajerial ownership }= \\
\text { stock of bosrd of com+stock of director } \\
\text { total share }\end{array}$ & Ratio \\
\hline
\end{tabular}

\section{Data analysis technique}

Test data analysis was performed using regression analysis with variavel moderating. analysis test conducted to determine whether the moderating varaibel used in this study serves as a moderating variable, independent variable or both

\section{EMPIRICAL RESULT AND CONCLUSION}

\section{A. Empirical Result}

This study aimed to examine the effect of conservatism on equity valuation with corporate governance variable as moderating variable. The following test results by using regression: 
Table 1

Model Summary

\begin{tabular}{|c|c|c|}
\hline Model 1 & $\begin{array}{l}\text { R squere } \\
\text { change }\end{array}$ & Sign \\
\hline Conservatism & 0.119 & 0.000 \\
\hline Consevatism + Boad of commissioners & 0.001 & 0.542 \\
\hline $\begin{array}{l}\text { Consevatism }+ \text { Boad of commissioners }+ \\
\text { (Consevatism*Boad of commissioners) }\end{array}$ & 0.006 & 0.116 \\
\hline Model 2 & & \\
\hline Conservatism & 0.119 & 0.000 \\
\hline Consevatism + manajerial ownership & 0.000 & 0.730 \\
\hline $\begin{array}{l}\text { Consevatism + manajerial ownership+ } \\
\text { (Consevatism + manajerial ownership) }\end{array}$ & 0.008 & 0.067 \\
\hline
\end{tabular}

The resulting regression equation in this study:

$$
\begin{aligned}
& Y=35,371+\beta_{1} 0,041+1,913 \\
& Y=9,863+\beta_{1} 0,849+\beta_{2} 0,495-\beta_{3} 0,011+15,832 \\
& Y=12,092+\beta_{1} 0,773+\beta_{4} 0,479-\beta_{5} 0,010+15,832
\end{aligned}
$$

\section{B. Conclusion}

Studies show conservatism affect the equity valuation. accounting conservatism generate profit more qualified for this principle prevents companies taking action to exaggerate profits and helps users of financial statements to the presentation of earnings and assets not overstate. The higher the level of conservatism that increasingly reflects the reality of the financial statements and this would be a good response from investors.

Board of commirioners does not strengthen the influence of conservatism on equity valuation. Application of accounting conservatism at the company are not affected by the presence of board of commissioners. Board of commissioners in this case is not instrumental in establishing accounting principles for the application of accounting principles must be in accordance with PSAK not a policy of board of commissioners.

Corporate governance in this study is managerial ownership does not strengthen the influence of conservatism on equity valuation. manejerial ownership in manufacturing companies does not affect the management to apply accounting conservatism. The results of this study contrast with the theory of managerial ownership could reduce opportunistic actions of management. One of them using accounting conservatism in the method of recording, there by increasing the quality of earnings and value company [9].

\section{Bibliography}

R. W. D. Paramita, "PENGARUH KETEPATWAKTUAN PENYAMPAIAN LAPORAN KEUANGAN TERHADAP RESPON LABA AKUNTANSI," WIGA-Jurnal Penelit. Ilmu Ekon., vol. 4, no. 2, pp. 39-44, 2014.

[2] R. W. D. Paramita, "THE WINDOW INFORMATION FOR INVESTOR ON ACCOUNTING PROFIT FORECASTING," $J$. Terap. Manaj. dan Bisnis, vol. 3, no. 2, pp. 193-204, 2017.

[3] V. J. Richardson, "INFORMATION ASYMMETRY AND EARNINGS MANAGEMENT : SOME EVIDENCE BY University of Kansas," 1998.

[4] R. Ball and R. Ball, "Working Paper No . 09-16 Econometrics of the Basu Asymmetric Timeliness Coefficient and Accounting Conservatism Valeri Nikolaev University of Chicago Booth School of Business and Accounting Conservatism," no. 9.

[5] S. Basu, "Discussion of " Conditional and Unconditional Conservatism : Concepts and Modeling,"," no. 12, pp. 311-321, 2005.

[6] M. C. Jensen and W. H. Meckling, "Theory of the Firm : Managerial Behavior, Agency Costs and Ownership Structure Theory of the Firm : Managerial Behavior, Agency Costs and Ownership Structure."

[7] C. A. Botosan, "Disclosure and the cost of capital : what do we know ?," no. August 1994, pp. 31-40, 2006.

[8] S. Veronica and Y. S. Bachtiar, "CORPORATE GOVERNANCE, INFORMATION ASYMMETRY, AND EARNINGS MANAGEMENT," vol. 2, no. 1, pp. 77-106, 2005.
Offerings : Reducing Information Asymmetry or Hyping the Stock ?," no. 734.

[10] T. Loder, M. Van Alstyne, and R. Wash, "Information Asymmetry and Thwarting Spam," vol. 6, no. c, 2004.

[11] P. M. Healy and K. G. Palepu, "Information asymmetry, corporate disclosure, and the capital markets: A review of the empirical disclosure literature," J. Account. Econ., vol. 31, no. 1-3, pp. 405440, 2001.

[12] R. Z. Wang, "The Asymmetric Market Valuation of Nonrecurring Items and Accounting Conservatism."

[13] R. C. Pimentel, "Unexpected Earnings, Stock Returns, and Risk in the Brazilian Capital Market *, **,” no. June 2014, pp. 290-303, 2015.

[14] "How important are earnings announcements as an information source?* SUDIPTA BASU,."

[15] P. O. G. P. H. D, "THE ROLE OF CORPORATE GOVERNANCE IN TRANSITION ECONOMIES : CONTRIBUTION AND DEVELOPMENT," no. 5, pp. 5-12, 2016.

[16] R. Wijayanti and D. Paramita, "TIMELINESS SEBAGAI VARIABEL INTERVENING UNTUK," vol. 4, no. 1, pp. 34-42, 2014.

[17] "CORPORATE GOVERNANCE, EARNINGS DAN RETURN SAHAM EDY SURANTA PRANATA PUSPA MIDIASTUTY Simposium Riset Ekonomi II Surabaya , 23-24 November 2005," no. November, pp. 23-24, 2005.

[18] E. Murwaningsari, "KEPEMILIKAN INSTITUSIONAL DAN KUALITAS AUDIT FUTURE EARNINGS RESPONSE COEFFICIENT," vol. 18, no. 2, pp. 161-171, 2014. 